\title{
The Distance Training Application to Improve the Literacy Ability of Mathematical Teacher on Madrasah Tsanawiyah
}

\author{
Makmun Hidayat ${ }^{1}$, Mustadji $^{2}$, Bachtiar Saiful Bachri ${ }^{3}$, Bakhrul Khair Amal ${ }^{4}$ \\ 1,2,3Postgraduate Student in Department of Education Technology Study Program, Universitas Negeri \\ Surabaya, Indonesia \\ ${ }^{4}$ Universitas Negeri Medan, Indonesia \\ Email:makmunhidayat1973@gmail.com,mustadji@unesa.ac.id, bachtiar@unesa.ac.id, \\ b4khrul.4m41@gmail.com
}

\begin{abstract}
The pandemic covid-19 and the development of information technology and communication is a resistance and challenge for those who are trained to innovate the training pattern. In practice, the distance training as multimedia based learning becomes an alternative implementation pattern that is widely applied by training institutions. In the implementation of this distance training, literacy skills of the participants are required. This study aims to explain the increase in literacy skills of Madrasah Tsanawiyah mathematics teachers through the application of distance training. This study is a quantitative descriptive study on a sample of mathematics teacher training participants at the Surabaya Religious Education and Training Center in 2021. The research design used a one sample pre test-post test with a test as a data collection technique. Then the data was processed using N-Gain analysis techniques and using t-test's SPSS paired sample test method. The results showed that there was an increase in literacy ability in general by 0.842 (high Gain category) with $t$ test results at $=0.05, d f=34$ of $16,952>t$ table (very significant category). Meanwhile, the literacy ability of mathematical content in the geometry aspect showed an increase of 0.618 (medium gain category) with $t$-test results at $=0.05, d f=34$ of $11,153>t$ table (very significant category). From the results of this study, it can be concluded that the application of distance training can improve the literacy skills of Madrasah Tsanawiyah mathematics teachers.
\end{abstract}

Keywords: covid-19; distance training; the literacy ability

\section{Introduction}

The ongoing training implementation process raises various obstacles. The current Covid-19 pandemic can be one of the obstacles due to the spread of the corona virusvery influential on the pattern of connectivity between humans and all aspects of life including the process of learning activities in the implementation of training. The development of technology and information, which has had a positive impact on the implementation of the training, has also become a challenge to continue to be able to carry out learning activities in the training program optimally. (Triyono; Febriani, RD; Hidayat, H.; Putri, Besti ND, 2019) (Susilo, 2019). In line with the adult learning strategy, online multimedia-based learning can be used as a solution. Organizing multimedia-based learning that is carried out online is one of the innovations in the training implementation system. Therefore, during the Covid-19 pandemic, such as the current distance training (PJJ) is mostly carried out by educational and training institutions. One of the skills that need to be developed in distance training is literacy skills. This literacy is the ability to access, understand, and use various learning resources intelligently to improve competence. Activities in this literacy include reading, viewing, listening, writing, and communicating activities with various learning resources, both in print, visual and digital forms. 
Judging from the applied aspect, literacy is also the ability to use the knowledge possessed to solve problems through critical thinking skills, analysis, creativity in finding solutions to problems, and communicating both orally and in writing. So literacy skills are absolutely mastered and developed by everyone, including the trainees.

The results of a survey conducted by the International Student Assessment PISA found that literacy culture in Indonesia ranks 64 out of 65 countries in the world, among students, literacy culture in Indonesia ranks 57 out of 65 countries. (Suranggaga, 2017), literacy skills have not become a culture among students both at the elementary school level (Akbar, 2017), the mathematical literacy ability level 3 in class IX students in Bandung is moderate and at level 4 is low (Purwasih, R.; Sari, NR; Agustina, S., 2018) literacy skills oriented to the scientific approach of high school students in biology learning are included in the medium category (Setiawan, 2019). The research results as stated above tend to focus on research conducted on students. So far, there are still few research results related to literacy skills involving teachers both in schools and madrasas. For this reason, research is needed that involves teachers as research subjects, especially with regard to their literacy skills.

This paper specifically seeks to explain the improvement of the literacy skills of mathematics teachers in madrasahs through the application of distance training. The literacy skills described include general literacy skills and mathematical literacy skills on geometric material. In addition, this paper also describes the level of significance of increasing teacher literacy skills after the implementation of distance training. These three elements are discussed sequentially in the discussion of this study. Furthermore, from the results obtained, an analysis was carried out on several matters relating to the two literacy skills of teachers, both general literacy and mathematical literacy in geometry material.

This paper is based on the hypothesis that there is an increase in the literacy ability of mathematics teachers after the implementation of distance training. This increase can be seen in general literacy skills and mathematical literacy skills. This paper also assumes that the distance training implemented can accommodate the various things needed by mathematics teachers to be able to improve their literacy skills.

\section{Review of Literatures}

\subsection{Distance Training (PJJ)}

Training is a series of activities designed to change very specific behaviors in predetermined ways. If the activity is done well, then participants are expected to reproduce the targeted behavior (Mustaji; Sugiarso, 2017). There is a view of social interaction in new media theory that categorizes media according to their proximity to face-to-face interaction (Antony et al in Syakur, 2020). Khairiyyah (2021) state that mathematics is an important part of the field of science. According to Irhamna (2020) mathematics is a universal science. Mathematics is also seen as the queen of science. The expected results from the implementation of a short-term oriented training, are instant, and easy to measure and the implementation of the training is not only related to the implementation of face-to-face or online learning processes, but also guarantees that what the trainees learn can be applied in the workplace and have an impact on improving the performance of employees who have attended the training. Generally, blended learning is considered as learning that combines faceto-face systems with mediation technology instruction (Hamid K, 2019). So training is learning that is specifically designed to improve employee performance in the current job that must be mastered. Therefore, the training delivery system should cover the instructional aspects in the 
classroom, the results of training in the workplace, and the benefits derived from training activities or better known as return on investment (ROI) (Ratna, 2016).

The system for organizing training during the Covid-19 pandemic that has been widely developed is distance training (PJJ) and is carried out online. This remote training system is able to create equal opportunities for employees to improve their competencies, expand participants' opportunities for literacy in the form of activities to access and utilize training materials, and increase participants' active participation in participating in learning activities during the training.(Nugraha, Firman; Restendi, Dedi; Triyanto, Agus, 2020). Distance training is implemented by applying the following principles: 1) individual differences; 2) work related; 3) motivation of training participants; 4) the activeness of the training participants; 5) selection of organizers and resource persons; 6) training implementation methods; and 7) principles of learning in training (Ratna, 2016). In addition, the implementation of distance training must also pay attention to aspects of independence in learning and the availability of learning materials. So distance training must be able to accommodate various matters relating to an effective training system to improve the competence of participants.

\subsection{Mathematical Literacy Ability}

Mathematical literacy is the knowledge and skills needed to understand the material, use numbers, apply appropriate mathematical operations in solving problems, and the ability to apply mathematical concepts in everyday life. Mathematical literacy ability supports the development of mathematical power, namely a person's ability to deal with mathematical problems and other contextual problems that are solved by applying their mathematical knowledge (Abidin; Yunus; Mulyati; Tita; Yunansah; Hana, 2017). In the notes of the National Council of Teachers Mathematics (NCTM, 2000) there are five competencies that teachers should develop in learning mathematics, namely: (1) mathematical problem solving; (2) mathematical communication; (3) mathematical reasoning; (4) mathematical connections; and (5) mathematical representation. Mathematical literacy skills combine these five abilities so that students can use their mathematical knowledge to solve contextual problems in everyday life.

In relation to distance training, mathematical literacy ability is the ability of individual trainees to access, formulate, use, and interpret mathematics training materials in various problem solving contexts. The literacy ability of the participants for the entire training material is hereinafter referred to as general literacy ability. Meanwhile, the literacy skills of the trainees towards mastery of mathematical content represented by one of the mathematical materials, namely the aspect of geometry, are hereinafter referred to as content literacy of geometry material.

\section{Research Methods}

\subsection{Material Objects}

The object of the material studied in this paper is the literacy ability of the mathematics teacher training participants at Madrasah Tsanawiyah in the province of East Java. The literacy ability in question includes general literacy skills because it covers all training materials and literacy skills in mathematics content, especially geometry material. The two literacy skills were described and further explained the significance level of the increase after the remote training was carried out at the Surabaya Religious Education and Training Center.

\subsection{Research Type and Data Type}

This research is quantitative descriptive. The types of data described are quantitative data obtained based on phenomena that occur and describe the literacy skills of Madrasah 
Tsanawiyah mathematics teachers before and after the implementation of distance training. Data taken from training participants prior to the implementation of the training hereinafter referred to as pre-test data. While the data taken after the next training is called post-test data.

\subsection{Participants}

Respondents in this study were mathematics teachers who participated in remote training at the Substantive Technical Training for Madrasah Tsanawiyah Mathematics Teachers at the Surabaya Religious Education and Training Center in 2021. The mathematics teachers were delegates from each district/city throughout the province of East Java.

\subsection{Data Collection Procedures and Techniques}

The research procedure carried out applies the design"One"-group PretestPosttest" (Sugiyono, 2010) to compare the situation before and after being given treatment in the form of delivering training materials that all of which can be accessed on the Moodle application PJJ Religious Education and Training Center Surabaya. designn this research as shown in Figure 1 below.

\section{$\mathrm{O}_{1} \mathrm{XO}_{2}$}

Figure 1. Desain "One-group Pretest-Posttest"

Information:

$\mathrm{X}=$ Petreatment in the form of remote delivery of training materials

$\mathrm{O}_{1}=$ Result of pretest before being given treatment

$\mathrm{O}_{2}=$ Result of posttest after being given treatment

A complete picture of the variables studied, data collection techniques and instruments required for data collection can be seen in Table 3.1 below.

Table 1. Variables, Data Collection Techniques and Research Instruments

\begin{tabular}{|c|c|c|c|}
\hline No & Variable & Data Collection Technique & Research Instruments \\
\hline 1 & $\begin{array}{l}\text { Mathematical literacy ability } \\
\text { (KLM) in general }\end{array}$ & Test Technique & $\begin{array}{l}\text { 1. KLM Pre-Test } \\
\text { Questions } \\
\text { 2. KLM Test Post } \\
\text { Questions }\end{array}$ \\
\hline 2 & $\begin{array}{l}\text { Mathematical literacy skills } \\
\text { (KLM) aspects of Geometry }\end{array}$ & Test Technique & $\begin{array}{l}\text { 1. Geometry Aspects of } \\
\text { KLM Pre-Test } \\
\text { Questions } \\
\text { 2. Geometry Aspects of } \\
\text { KLM Test Post } \\
\text { Questions }\end{array}$ \\
\hline
\end{tabular}

Note: to ensure the accuracy of the resulting data, the validity of the instrument will be tested first

\subsection{Data Analysis}

Quantitative data in the form of numbers from the results of the mathematical literacy ability test of the trainees were analyzed by comparing the pretest and posttest value data using the N-Gain test (normalized gain). (Meltzer, 2002), that is:

$$
<\boldsymbol{g}>=\frac{\% \text { actual gain }}{\% \text { potential gain }}=\frac{\% \text { postest score }-\% \text { pretest score }}{100-\% \text { pretest score }}
$$


Quantitative descriptive analysis is based on the N-Gain criteria, namely:

1) learning outcomes with "High gain" if $0.7<\boldsymbol{g}>$

2) learning outcomes with "Medium gain" if $0.3<\boldsymbol{g}><0.7$

3) learning outcomes with "Low gain" if $<\boldsymbol{g}><0.3$

Meanwhile, to test the research hypothesis in order to know how high the significance level of increasing the literacy ability of participants is, a t-test is carried out using SPSSpaired sample test methods, with steps following.

1) Meformulate a hypothesis

$\mathrm{H}_{0}$ : pretest $=$ posttest $:$ there is no increase in participants' literacy skills before and after the implementation of distance training for MTs mathematics teachers at the Surabaya Religious Education and Training Center

H1: pretest posttest : there is an increase in participants' literacy skills before and after the implementation of distance training for MTs mathematics teachers at the Surabaya Religious Education and Training Center

2) Determine the level of significance $\alpha=0.05$

3) Testi Statistics

This statistic is carried out using the SPSS paired sample test method program

4) Ktest Criteria

The test criteria are data from the results of the SPSS program with the following criteria: $\mathrm{H} 0$ is accepted if $\mathrm{t}$ count $<\mathrm{t}$ table for $\alpha=0.05$

$\mathbf{H}_{1}$ accepted if $\mathrm{t}$ count $>\mathrm{t}$ table for $\boldsymbol{\alpha}=0.05$

\section{Discussion}

\subsection{Results}

The data from the results of research on the application of online learning in distance training of Madrasah Tsanawiyah mathematics teachers are as follows.

\section{a. Literacy Ability Data for Distance Training Participants}

The data on the literacy skills of the distance training participants for Madrasah Tsanawiyah mathematics teachers are in the form of pre-test scores and post-test scores. The pre-test value is the value obtained from the training participants before they receive treatment, while the post-test value is the value obtained after the participants receive treatment in the form of remote training using the Moodle application. Researchers also took supporting data in the form of pre-test and post-test scores for Geometry Materials training. This data collection was intended to determine whether or not there was an increase in the participants' mathematical literacy skills, especially with regard to substantive mathematics. The data that has been obtained, then processed by calculating the average in each of the existing data.

Table 2. Literacy Ability Data MTs Mathematics Teacher Distance Training Participants in 2021 at the Surabaya Religious Education and Training Center

\begin{tabular}{ccccc}
\hline \multirow{2}{*}{ NO RESPONDENTS } & \multicolumn{2}{c}{ GENERAL LITERATURE } & \multicolumn{2}{c}{ GEOMETRY } \\
\cline { 2 - 5 } & PRE TEST & TEST & PRE TEST & TEST POST \\
\cline { 2 - 4 } & & &
\end{tabular}


POST

\begin{tabular}{|c|c|c|c|c|c|}
\hline 1 & Respondent1 & 34 & 90 & 42 & 80 \\
\hline 2 & Respondent 2 & 48 & 88 & 61 & 70 \\
\hline 3 & Respondent3 & 42 & 90 & 42 & 80 \\
\hline 4 & Respondent4 & 70 & 90 & 70 & 80 \\
\hline 5 & Respondent 5 & 50 & 96 & 60 & 75 \\
\hline 6 & Respondent6 & 46 & 94 & 59 & 75 \\
\hline 7 & Respondent7 & 38 & 88 & 60 & 75 \\
\hline 8 & Respondent8 & 62 & 90 & 62 & 80 \\
\hline 9 & Respondent9 & 62 & 96 & 73 & 85 \\
\hline 10 & Respondent10 & 32 & 92 & 32 & 85 \\
\hline 11 & Respondent11 & 46 & 90 & 46 & 90 \\
\hline 12 & Respondent12 & 22 & 88 & 22 & 80 \\
\hline 13 & Respondent13 & 34 & 88 & 34 & 90 \\
\hline 14 & Respondent14 & 52 & 78 & 52 & 85 \\
\hline 15 & Respondent15 & 74 & 100 & 74 & 85 \\
\hline 16 & Respondent16 & 46 & 90 & 46 & 70 \\
\hline 17 & Respondent17 & 64 & 96 & 64 & 85 \\
\hline 18 & Respondent18 & 78 & 96 & 78 & 90 \\
\hline 19 & Respondent19 & 46 & 96 & 46 & 85 \\
\hline 20 & Respondent20 & 44 & 96 & 44 & 85 \\
\hline 21 & Respondent21 & 46 & 94 & 47 & 85 \\
\hline 22 & Respondent22 & 56 & 94 & 74 & 85 \\
\hline 23 & Respondent23 & 42 & 88 & 57 & 90 \\
\hline 24 & Respondent24 & 28 & 90 & 55 & 75 \\
\hline 25 & Respondent25 & 58 & 90 & 62 & 80 \\
\hline 26 & Respondent26 & 32 & 94 & 55 & 85 \\
\hline 27 & Respondent27 & 10 & 96 & 40 & 85 \\
\hline 28 & Respondent28 & 44 & 90 & 65 & 90 \\
\hline 29 & Respondent29 & 70 & 94 & 70 & 80 \\
\hline 30 & Respondent30 & 42 & 96 & 42 & 85 \\
\hline 31 & Respondent31 & 52 & 92 & 52 & 85 \\
\hline 32 & Respondent32 & 74 & 86 & 74 & 85 \\
\hline 33 & Respondent33 & 58 & 96 & 73 & 90 \\
\hline 34 & Respondent34 & 38 & 96 & 59 & 90 \\
\hline 35 & Respondent35 & 34 & 84 & 34 & 80 \\
\hline & AVERAGE & 47.83 & 91.77 & 55.03 & 82.86 \\
\hline
\end{tabular}

\section{b. Data Analysis of Distance Training Participants' Mathematical Literacy Ability}

Based on the data as contained in Table 4.1, further analysis was carried out based on the N-Gain formula and the following results were obtained.

1. The literacy skills of the Madrasah Tsanawiyah mathematics teacher training participants are as follows.

$$
\begin{aligned}
<\mathrm{g}> & =\frac{\% \text { actual gain }}{\% \text { potential gain }}=\frac{\% \text { postest score- } \% \text { pretest score }}{100-\% \text { pretest score }} \\
& =\frac{91,77-47,83}{100-47,83} \\
& =0.842278204 \text { (High Gain) }
\end{aligned}
$$

3. While the ability of mathematical literacy in the Essential Materials of Geometry, the following results were obtained. 


$\begin{aligned}<\mathrm{g}> & =\frac{\% \text { actual gain }}{\% \text { potential gain }}=\frac{\% \text { postest score- } \% \text { pretest score }}{100-\% \text { pretest score }} \\ & =\frac{82,86-55,03}{100-55,03} \\ & =0.618805591 \text { (Medium Gain) }\end{aligned}$

Furthermore, the researchers conducted a significance test (t-test using the SPSS paired sample test method) on improving the literacy skills of participants before and after the implementation of distance training for Madrasah Tsanawiyah mathematics teachers. This ttest is also intended to test the research hypothesis and the following results are obtained.

Table 3. Literacy Ability t-test M'Ts Mathematics Teacher Distance Training Participants in 2021 at the Surabaya Religious Education and Training Center

Paired Samples Test

\begin{tabular}{|c|c|c|c|c|c|c|c|c|c|}
\hline & & \multicolumn{5}{|c|}{ Paired Differences } & \multirow[b]{3}{*}{$\mathrm{t}$} & \multirow[b]{3}{*}{ df } & \multirow[b]{3}{*}{ Sig. (2-tailed) } \\
\hline & & \multirow[b]{2}{*}{ Mean } & \multirow[b]{2}{*}{ Std. Deviation } & \multirow{2}{*}{$\begin{array}{l}\text { Std. Error } \\
\text { Mean }\end{array}$} & \multicolumn{2}{|c|}{$\begin{array}{l}95 \% \text { Confidence Interval of the } \\
\text { Difference }\end{array}$} & & & \\
\hline & & & & & Lower & Upper & & & \\
\hline Pair 1 & $\begin{array}{l}\text { Pos Tes Diklat - Pre Tes } \\
\text { Diklat }\end{array}$ & 43,94286 & 15,33535 & 2,59215 & 38,67498 & 49,21074 & 16,952 & 34 &, 000 \\
\hline Pair 2 & $\begin{array}{l}\text { Pos Tes Geometri - Pre } \\
\text { Tes Geometri }\end{array}$ & 27,82857 & 14,76181 & 2,49520 & 22,75771 & 32,89943 & 11,153 & 34 &, 000 \\
\hline
\end{tabular}

4. Based on the results of the t-test using the SPSS paired sample test method on the pretest post-test of literacy skills in general, participants after participating in distance training for mathematics teachers obtained the results of $\mathrm{t}$ arithmetic at $=0.05, \mathrm{df}=34$ of 16, 952 $>\mathrm{t}$ table at $=0.05, \mathrm{df}=34$ of 1.689. In this case, it can be seen that $\mathrm{H} 0$ is rejected and $\mathrm{H} 1$ is accepted. That is, pretest posttest or there is an increase in the literacy skills of participants in the Mathematics teacher training of Madrasah Tsanawiyah before and after the implementation of distance training. While the results of the t-test on the participants' mathematical literacy skills after following the essential geometry material obtained the results of $\mathrm{t}$ arithmetic at $=0.05, \mathrm{df}=34$ at $11,153>\mathrm{t}$ table at $=0.05, \mathrm{df}=34$ at 1.689. In this case, it can be seen that $\mathrm{H} 0$ is rejected and $\mathrm{H} 1$ is accepted.

Based on the results of the analysis of research data, it can be stated that the distance training held at the Surabaya Religious Education and Training Center has been able to improve the literacy skills of Madrasah Tsanawiyah mathematics teachers, both general literacy and mathematical content literacy. This is certainly inseparable from various factors that influence it either directly or indirectly. These factors can be described in the following discussion.

\subsection{Discussion}

a. The increase in literacy skills in general for distance training participants for Madrasah Tsanawiyah mathematics teachers is 0.842 with the "high" category based on the NGain analysis criteria, because $0.7<\mathrm{g}>$ (Meltzer, 2002). This upgradeinfluenced by several factors. Based on the results of filling out a google form questionnaire conducted by the training participants, the factors that directly affect the improvement of literacy skills include: the high motivation of participants in participating in the training, the ease of participants in accessing and utilizing training materials that have been prepared by resource persons in a learning management system based on the Moodle application., the level of novelty of the uploaded material so that it becomes an attraction for 
participants to learn and master it because this is certainly in accordance with their needs; there is a training task that must be done so that participants must learn and master the material that has been delivered. Meanwhile, factors that indirectly affect the improvement of participants' literacy skills include: the availability of networks that make it easier for participants to access and utilize all sources of information and training materials, assistance and support from peers and other teachers who do not attend the training. and complete all tasks during the training, the completeness of the content uploaded by widyaiswara in the Moodle learning management system also makes it easier for participants to find ways to solve problems raised during the training. The results of this analysis are in line with the results of research proposed by previous researchers with different research subjects (Imran, AP; Kadir; Anggo, M., 2017), (Pakpahan, 2016), (Mahdiansyah \& Rahmawati, 2014).

b. The increase in mathematical literacy skills in geometry material for distance training participants for Madrasah Tsanawiyah mathematics teachers is 0.618 with the "medium" category based on the N-Gain analysis criteria, because $0.3<\mathrm{g}><0.7$ (Meltzer, 2002), influenced by several factors. Based on the results of the questionnaire submitted by the training participants, it was found that the factors that became a problem in solving geometry problems included: the level of material difficulty, where geometry material is one of the mathematical materials with a high level of complexity and requires a high level of ability to be able to solve the problem. the problem. The time provided by the committee in solving the problems or geometry questions submitted is too little, it takes a long time to solve these problems. Based on the statement above, it can be stated that the factors that affect the literacy level of the geometry content of the Madsarah Tsanawiyah mathematics teacher are more on the problem of the level of complexity of the material so that it takes more than enough time to be able to solve these problems. This is in accordance with the results of previous studies on geometry material(Budiarto, 2002), (Azhar, WS; Senjayawati E., 2021), (Nanna, A. Wilda Indra; Pratiwi, E.; Anggraeni, C., 2020) (Hadiyanto, 2019).

c. The high level of significance of increasing literacy skills both in general and in the content of mathematical material aspects of geometry shows a tendency that the implementation of distance training by utilizing information and communication technology and utilizing the learning management system with the help of the Moodle application makes it easy for participants to access the material and use it to improve competence. This is what supports the heightthe results of $\mathrm{t}$ arithmetic at $=0.05, \mathrm{df}=$ 34 of $16.952>\mathrm{t}$ table for general literacy skills, and the results of $\mathrm{t}$ arithmetic at $=0.05$, $\mathrm{df}=34$ of $11.153>\mathrm{t}$ table at $=0,05 \mathrm{df}=34$ of 1.689 for the mathematical literacy ability of the essential material of geometry. Madrasah Tsanawiyah mathematics teachers tend to access and utilize all available teaching materials and materials. Because the problems posed are in accordance with the material provided, so that it can support the high level of significance in improving literacy skills. This motivation should continue to be developed by teachers to always carry out literacy by utilizing other learning resources so that they can improve performance and competence in implementing mathematics learning in madrasas.

\section{Conclusion}

The results of the research and discussion show that the application of distance training can improve the literacy skills of Madrasah Tsanawiyah mathematics teachers. Literacy ability in general increased in the high category according to the N-gain analysis criteria of 0.842 with a t-count significance level of 16.952. This increase is supported by the convenience of participants to access training materials, making it easier for participants to 
find appropriate references in solving the problems posed. Literacy ability in mathematical content increased in the medium category according to the $\mathrm{N}$-gain analysis criteria of 0.618 with a t-count significance level of 11.153. This increase in mathematical content literacy is certainly influenced by the high level of complexity of the geometric material used as the measured variable. This is a new finding in this study, because so far there has been no research that has focused on mathematical content literacy for mathematics teachers at Madrasah Tsanawiyah.

The weakness of literacy research on mathematical content is only limited to geometry material, it is still necessary to develop research on other mathematical material content, so that a complete picture of the literacy skills of Madrasah Tasawiyah teachers in all aspects of the material can be obtained. Therefore, further research is needed to complete this research.

\section{References}

Abidin; Yunus; Mulyati; Tita; Yunansah; Hana. (2017). Pembelajaran Literasi: Strategi meningkatkan kemampuan literasi matematika, sains, membaca, dan menulis. Jakarta: Bumi Aksara.

Akbar, A. (2017). Membudayakan literasi dengan program 6 M di Sekolah Dasar. Jurnal Pendidikan Sekolah Dasar UNTIRTA Vol. 3 No. 1, 2.

Azhar, W.S.; Senjayawati E. (2021). Analisis kelasahan siswa SMK dalam menyelesaikan soal materi geometri ruang. Jurnal Pembelajaran Matematika Inovatif Vol. 4 No. 1, 185 192 Tersedia https://journal.ikipsiliwangi.ac.id/index.php/jpmi/article/viewFile/5705/2145.

Budiarto, M. T. (2002). Bentuk kesalahan dalam menyelasaikan permasalahan geometri. Surabaya: Pusat Penelitian Universitas Negeri Surabaya.

Carman , J. (2005). Blended learning design: five key ingredients.

Hadiyanto, F. R. (2019). Analisis kesalahan siswa kelas VII dalam menyelesaikan soal cerita pada materi geometri dengan menggunakan Newman's Procedure. Jurnal Kajian Pembelajaran Matematika Vol. 3 No. 2, 67 - 77 Tersedia di http://journal2.um.ac.id/index.php/jkpm/article/view/9546.

Hamid, K. A. et.al. (2019). Evaluation of Implementation of Blanded Learning Implementation in Universitas Negeri Medan. Britain International of Linguistics, Arts and Education (BIoLAE) Journal Vol. 1 (2): 224-231.

Irhamna, Amry, Z., and Syahputra, H. (2020). Contribution of Mathematical Anxiety, Learning Motivation and Self-Confidence to Student's Mathematical Problem Solving. Budapest International Research and Critics in Linguistics and Education (BirLE) Journal Vol 3 (4): 1759-1772.

Imran, A.P.; Kadir; Anggo, M. (2017). Analsis literasi matematika dan keyakinan matematika siswa SMA Negeri di kota Kendari. Jurnal Pendidikan MatematikaVol. 8 No. 2, 159 168. Tersedia di https://media.neliti.com/media/publications/317628-analisis-literasimatematik-dan-keyakina-6e577b5a.pdf.

Khairiyyah, A., Mulyono, and Fauzi, K.M.A. (2021). The Learning Effect of Blended Learning Based on Google Class Room and Initial Mathematics on Mathematic Representation and Resilience of Students in the Covid-19 Pandemic. Britain International of Linguistics, Arts and Education (BIoLAE) Journal Vol. 3 (1): 63-76.

Khikmiyah, F. (2016). Pengembangan buku ajar litearsi matematika untuk pembelajaran di SMP. Jurnal Silogisme: Kajian Ilmu Matematika dan Pembelajarannya. Desember 2016, Vol. 1 No. 2. ISSSN: 2527-6182, 23-31.

Mahdiansyah \& Rahmawati. (2014). Literasi Matematika Siswa Pendidikan menengah: Analisis menggunakan desain tes inetrnasional dengan konteks Indonesia. Jurnal Pendidikan 
dan Kebudayaan, $452 \quad-\quad 469 \quad 4 \quad$ Tersedia di

https://www.neliti.com/publications/178854/literasi-matematika-siswa-pendidikanmenengah-analisis-menggunakan-desain-tes-in\#id-section-content.

Meltzer, D. (2002). The relationship between mathematics preparation andconseptual lerning gains in physics: A possible "hidden variable" in diagnostic pretest scores. Ames Lowa 50011: Department of Physics and Astronomy, Lowa Sate University.

Mustaji; Sugiarso. (2017). Pengelolaan pelatihan: Upaya peningkatan kinerja dalam bidang bisnis dan pendidikan. Surabaya: Unesa University Press.

Nanna, A. Wilda Indra; Pratiwi, E.; Anggraeni, C. (2020). Analisis kesalahan mahasiswa PGSD dalam menyelesaikan masalah geometri. Sigma Vol. 6 No. 1, 60 - 77 Tersedia di https://www.researchgate.net/profile/Enditiyas-Pratiwi/publication/346150164.

NCTM. (2000). Handbook of researchon mathematic teaching and learning. Editor: Douglas A. Grows. USA: Mac Millan Library reference.

Nugraha, Firman; Restendi, Dedi; Triyanto, Agus. (2020). Pengembangan sistem pelatihan jarak jauh berbasis moodle di Balai Diklat Keagamaan Bandung. Andragogi: Jurnal Diklat Teknis Pendidikan dan Keagamaan Vol. 8 No. 2, 540.

Pakpahan, R. (2016). Faktor-faktor yang memengaruhi capaian literasi matematika siswa Indonesia dalam Pisa 2012. Jurnal Pendidikan dan Kebudayaan Vol 1 No. 3 , 331 - 347 Tersedia di https://core.ac.uk/download/pdf/322566029.pdf.

Purwasih, R.; Sari, N.R.; Agustina,S. (2018). Analisis kemampuan literasi matematika dan mathematical habits of mind siswa SMP pada pateri bangun ruang sisi datar. Numeracy Vol 5 No. 1, 67.

Ratna, S. (2016). Perancangan sistem diklat. Jakarta: Lembaga Administrasi Negara.

Setiawan, A. R. (2019). Efektivitas pembelajaran biologi berorientasi literasi santifik. Thabiea: Journal of Natural Science Teaching Vol. 2 No. 2, IAIN Kudus, 83.

Sugiyono. (2010). Metode Penelitian Pendidikan (Pendekatan Kuantitatif, Kualitatif, dan R\&D). Bandung: Alfabeta.

Suragangga, I. N. (2017). Mendidik lewat literasi untuk pendidikan berkualitas. Jurnal Penjaminan Mutu, LPM Institut Hindu Dharma Negeri, 154.

Susilo, B. (2019). Dampak positif perkembangan teknologi informasi terhadap tumbuh kembang anak. Seminar Nasional Hasil Pengabdian Kepada Masyarakat 2019 (pp. 139 - 143). Pontianak: SINDIMAS-STMIK Tersedia di http://www.sisfotenika.stmikpontianak.ac.id/index.php/sindimas/article/view/552/3 58.

Syakur, A., Sugirin, Widiarni. (2020). The Effectiveness of English Learning Media through Google Classroom in Higher Education. Britain International of Linguistics, Arts and Education (BIoLAE) Journal Vol. 2 (1): 475-483.

Triyono; Febriani, R.D.; Hidayat, H.; Putri, Besti N.D. (2019). Pelatihan penggunaan teknologi informasi kepada guru bimbingan dan konseling. Jurnal PkM Ilmu Kependidikan Vol 2 No 1,74 . 